\title{
Synergistic antitumor effect of dual PI3K and mTOR inhibitor NVP-BEZ235 in combination with cisplatin on drug-resistant non-small cell lung cancer cell
}

\author{
HAO ZHU, YUHUAN SHI, XIUXIU JIAO, GANG YANG, RONG WANG and YONGFANG YUAN \\ Department of Pharmacy, Shanghai Ninth People's Hospital, Shanghai Jiao Tong University \\ School of Medicine, Shanghai 200011, P.R. China
}

Received March 14, 2020; Accepted September 17, 2020

DOI: $10.3892 / \mathrm{ol} .2020 .12189$

\begin{abstract}
Cisplatin resistance is an obstacle for the effective treatment of non-small cell lung cancer (NSCLC). The combined use of two or more chemotherapeutic agents displays advantages for the clinical treatment of drug-resistant lung cancer. The present study aimed to assess the synergy of the dual PI3K/Akt/mTOR signaling pathway inhibitor NVP-BEZ235 and cisplatin, a chemotherapeutic agent, on proliferation, apoptosis, cell cycle arrest and protein expression in cisplatin-resistant NSCLC A549/diamminedichloroplatinum resistance (DDP) cells. Cell proliferation was determined by performing Cell Counting Kit 8 and colony formation assays. Combination index (CI) was used to assess the combinatorial effects of NVP-BEZ235 and cisplatin. Cellular apoptosis and cell cycle arrest were detected via flow cytometry. Western blotting was performed to evaluate protein expression levels relative to $\beta$-actin. Cisplatin and NVP-BEZ235 displayed the strongest synergy $\left(\mathrm{CI}_{50}=0.23\right)$ at the mass ratio of 10:1. The half inhibitory concentrations of cisplatin and NVP-BEZ235 at 10:1 were 1.53 and $0.15 \mu \mathrm{g} / \mathrm{ml}$, respectively. Compared with the control group, the combination of cisplatin and NVP-BEZ235 induced cell apoptosis and inhibited colony formation. Furthermore, compared with the control group, phosphorylation of Akt and p70S6 Kinase was significantly inhibited and cell cycle was arrested at $\mathrm{G}_{0} \mathrm{G}_{1}$ phase in the combination treatment group. The expression levels of drug efflux proteins, such as multidrug resistance-associated protein 1 and ATP-binding cassette sub-family G member 2, were significantly decreased when A549/DDP cells were treated with a combination of cisplatin and NVP-BEZ235
\end{abstract}

Correspondence to: Professor Yongfang Yuan, Department of Pharmacy, Shanghai Ninth People's Hospital, Shanghai Jiao Tong University School of Medicine, 639 ZhiZao Ju Road, Shanghai 200011, P.R. China

E-mail:nmxyyf@126.com

Key words: drug resistance, non-small cell lung cancer, cisplatin, NVP-BEZ235, combination therapy compared with the control group. Collectively, the present study indicated that the combined treatment of cisplatin and NVP-BEZ235 displayed synergistic antitumor effects on drug-resistant A549/DDP cells, by which the antiproliferative effects may occur via inhibition of the PI3K/Akt/mTOR signaling pathway and downregulation of drug efflux.

\section{Introduction}

Lung cancer is one of the most common malignant tumors, with the highest incidence $(11.6 \%)$ and mortality rates $(18.4 \%)$ according to the GLOBOCAN 2018 estimates of cancer incidence and mortality produced by the International Agency for Research on Cancer (1). Lung cancer can be divided into two primary types: Non-small cell lung cancer (NSCLC) and small cell lung cancer (2) It is estimated that $\sim 83 \%$ of patients with lung cancer suffer from NSCLC, and $65 \%$ of patients with NSCLC are diagnosed when the disease is already in an advanced or metastatic stage, which often results in a poor prognosis $(2,3)$.

Up to now, platinum-based adjuvant chemotherapy after complete resection has become a standard treatment strategy for patients with stage II-IIIA NSCLC and for individuals who cannot be treated with targeted cancer therapy $(4,5)$. Cis-diamminedichloroplatinum (DDP; cisplatin), one of the most widely used platinum-based drugs for lung cancer, can kill cancer cells by interfering with DNA synthesis and RNA transcription to induce cell apoptosis (6). Nevertheless, the prognosis of patients with advanced or metastatic NSCLC treated with cisplatin alone is poor (7) One of the challenges for the effectiveness of cisplatin treatment is drug resistance, which may be intrinsic or acquired after several cycles of chemotherapy. As a result, increasing the dose of chemotherapeutic agents does not improve therapeutic efficacy, but may cause severe side effects and lead to chemotherapy failure (8). The mechanisms underlying drug resistance are complicated and are not completely understood. Possible mechanisms might include overactivation of the PI3K/Akt/mTOR signaling pathway and overexpression of drug efflux proteins, such as ATP-binding cassette (ABC) transporters (9-12). At present, using a combination of two or more chemotherapeutic drugs is an effective strategy 
to improve the efficacy of chemotherapy and reverse drug resistance in different tumors (13-16).

Recently, the PI3K/Akt/mTOR signaling pathway has emerged as a crucial signaling pathway in cancer cell proliferation, metabolism, migration, angiogenesis and metastasis (17). Upregulation of the signaling pathway has been associated with poor prognosis in patients with cancer and may even confer resistance to chemotherapy in various tumors, including breast cancer, colorectal cancer and lung cancer $(9,18,19)$. Therefore, targeting the PI3K/Akt/mTOR signaling pathway using specific kinase inhibitors serves as a pivotal approach for drug-resistant cancer treatment (19-22). Upregulation of $\mathrm{ABC}$ transporters is another major cause for chemoresistance of different types of cancer, such as hepatocellular carcinoma and colorectal carcinoma (23). The ABC transporters are cell membrane proteins that can efflux chemotherapeutic agents out of cancer cells in an ATP-dependent manner, and ultimately lead to reduced intracellular accumulation of drugs and chemotherapy failure $(11,12,24)$. The ABC transporter super family consists of several members based on their structure. Among them, ABCB1 (P-glycoprotein), ABCC1 [multidrug resistance-associated protein 1 (MRP1)] and ATP-binding cassette sub-family $\mathrm{G}$ member 2 (ABCG2) are the most frequently upregulated proteins in cancer cells $(25,26)$. Notably, researchers also demonstrated that various signaling molecules, such as ERK1/2, PI3K/Akt and NF- $\kappa \mathrm{B}$ (p65), can regulate the expression of $\mathrm{ABC}$ transporters, such as ABCC1 (27) The aforementioned findings indicate that inhibiting the PI3K/Akt/mTOR signaling pathway and reducing the expression of drug efflux transporters in drug-resistant tumor cells may effectively induce cell death and reverse drug resistance.

NVP-BEZ235, a novel dual PI3K/Akt/mTOR inhibitor, which overcomes certain intrinsic disadvantages of single Akt or mTOR inhibitors, can kill various cancer cells via inhibiting dual PI3K/Akt and mTOR signaling pathways (28). Several researchers have reported that NVP-BEZ235 can reverse different types of drug-resistant cancer, such as multidrug-resistant acute myeloid leukemia cell lines, the cisplatin-resistant triple negative breast cancer cell line (HCC38) and cisplatin-resistant human bladder cancer cell lines $(20,21,29)$. Furthermore, combined treatment of NVP-BEZ235 and chemotherapeutic agents displayed significant synergistic effects on drug-resistant tumors (30). Currently, only one report has suggested that there is a synergistic action between NVP-BEZ235 and cisplatin in cisplatin-resistant NSCLC A549 cell (31). Nevertheless, the mechanisms have not been fully explained and elucidated.

The present study initially evaluated the synergistic antiproliferative effects of cisplatin and dual PI3K/Akt/mTOR inhibitor NVP-BEZ235 on the cisplatin-resistant NSCLC A549 cell line in vitro. Furthermore, the underlying cellular mechanism was investigated.

\section{Materials and methods}

Cell culture. The human NSCLC cell line (A549) and a cisplatin-resistant cell line (A549/DDP) were obtained from The Cell Bank of Type Culture Collection of the Chinese Academy of Sciences. Cells were cultured in a humidified atmosphere with $5 \% \mathrm{CO}_{2}$ at $37^{\circ} \mathrm{C}$ in RPMI-1640 medium (Hyclone; Cytiva) supplemented with $10 \%$ FBS (Gibco; Thermo Fisher Scientific, Inc.), $100 \mathrm{U} / \mathrm{ml}$ penicillin and $100 \mathrm{mg} / \mathrm{ml}$ streptomycin (Gibco; Thermo Fisher Scientific, Inc.). A549/DDP cells were maintained in the aforementioned medium containing $1.5 \mu \mathrm{g} / \mathrm{ml}$ cisplatin (Sigma-Aldrich, Merck KGaA).

Chemicals and reagents. NVP-BEZ235 was purchased from Selleck Chemicals. DMSO was purchased from Aladdin Industrial Co., Ltd. (https://www.aladdin-e.com) Cisplatin was purchased from Sigma-Aldrich (Merck KGaA). The Cell Counting Kit-8 (CCK-8) assay, BCA Protein Assay kit, Cell Cycle Analysis kit, Annexin V-FITC Apoptosis Detection kit, RIPA lysis buffer and SDS-PAGE protein-loading buffer (5X) were purchased from Beyotime Institute of Biotechnology. Giemsa stain was purchased from Shanghai Fushen Biotechnology Co., Ltd. The monoclonal Akt (cat. no. 4691S), phosphorylated (p)-Akt (cat. no. 2965S), p70-S6 Kinase (p70S6K; S6K; cat. no. 2708S), p-p70 S6 Kinase (p-p70S6K; p-S6K; cat. no. 9234S), ABCG2 (cat. no. 42078S), MRP1 (cat. no. 14685S) and $\beta$-actin (cat. no. 4970S) rabbit antibodies were purchased from Cell Signaling Technology, Inc. All primary antibodies were used at a dilution of 1:1,000. The HRP-labeled goat anti-rabbit IgG secondary antibody (cat. no. 111-035-003) was purchased from Jackson ImmunoResearch Laboratories, Inc. The secondary antibody was used at a dilution of 1:5,000.

Cell proliferation assay. NVP-BEZ235 was dissolved in DMSO to obtain a $1 \mathrm{mg} / \mathrm{ml}$ stock concentration. Cisplatin was dissolved in DMSO to obtain a $10 \mathrm{mg} / \mathrm{ml}$ stock concentration. Both NVP-BEZ235 and cisplatin stock solutions were stored at $-20^{\circ} \mathrm{C}$ before use and then further diluted in RPMI-1640 media to the desired concentrations (cisplatin, 0.04 50 $\mu \mathrm{g} / \mathrm{ml}$; NVP-BEZ235, 0.08 60 $\mu \mathrm{g} / \mathrm{ml}$ ). As a control, cells were incubated with fresh media containing an equal volume of DMSO (an equal volume of DMSO to media).

Cell proliferation in vitro was measured by performing the CCK-8 assay, according to the manufacturer's protocol. Briefly,

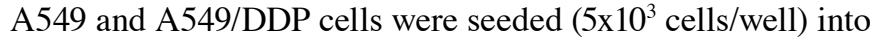
96-well plates and allowed to adhere overnight in a humidified atmosphere with $5 \% \mathrm{CO}_{2}$ at $37^{\circ} \mathrm{C}$. Subsequently, cell media was removed and cells were treated at $37^{\circ} \mathrm{C}$ for $48 \mathrm{~h}$ with different concentrations of cisplatin and NVP-BEZ235. After incubation, cells were washed with PBS and $15 \mu \mathrm{l}$ CCK-8 reagent was added to each well for $2 \mathrm{~h}$ at $37^{\circ} \mathrm{C}$. Samples were analyzed using a Bio-Rad 680 microplate reader (Bio-Rad Laboratories, Inc) at a wavelength of $450 \mathrm{~nm}$ with a reference wavelength $(650 \mathrm{~nm})$. The inhibitory rates on cell proliferation were calculated according to the following equation: Inhibition rate (\%) $=\left[\left(\mathrm{A}_{450 \text { control }}-\mathrm{A}_{450 \text { sample }}\right) /\left(\mathrm{A}_{450 \text { control }}\right)\right] \times 100$.

Combinatorial effects of cisplatin and NVP-BEZ235. The proliferative effects of drug combinations were evaluated by performing the CCK-8 assay. Briefly, A549/DDP cells were seeded $\left(5 \times 10^{3}\right.$ cells/well) into 96 -well plates and allowed to adhere overnight in a humidified atmosphere with $5 \% \mathrm{CO}_{2}$ at $37^{\circ} \mathrm{C}$. Subsequently, cell media was replaced with drugs of different mass ratios (cisplatin:NVP-BEZ235 at 15:1, 10:1, 5:1, 1:1 or 1:5) at various concentrations (cisplatin, $0.02 \sim 45 \mu \mathrm{g} / \mathrm{ml}$; 
NVP-BEZ235, 0.004 75 $\mu \mathrm{g} / \mathrm{ml})$. Control cells were incubated with fresh media containing an equal volume of DMSO. Clinically, drug dosage is calculated by mass ratios, instead of molar ratios. Thus, mass ratios were selected in the present study. Cells were incubated at $37^{\circ} \mathrm{C}$ for $48 \mathrm{~h}$. Following incubation, cells were washed with PBS and $15 \mu$ l CCK- 8 reagent was added to each well for $2 \mathrm{~h}$ at $37^{\circ} \mathrm{C}$. Samples were analyzed using a microplate reader at a wavelength of $450 \mathrm{~nm}$ with a reference wavelength. The inhibitory rates on cell proliferation were calculated according to the following equation: Inhibition rate $(\%)=\left[\left(\mathrm{A}_{450 \text { control }}-\mathrm{A}_{450 \text { sample }}\right) /\left(\mathrm{A}_{450 \text { control }}\right)\right] \times 100$.

Combination index analysis (CI) was used to assess the synergistic antitumor effects of cisplatin and NVP-BEZ235 in A549/DDP cells. CI was calculated according to the following formula: CI $x=(\text { Dose })_{1} /(\operatorname{Dose} x)_{1}+(\text { Dose })_{2} /(\operatorname{Dose} x)_{2}$, where (Dose) $)_{1}$ and (Dose) $)_{2}$ represent the dose of drug 1 (cisplatin) and drug 2 (NVP-BEZ235) in combination therapy that inhibit $x \%$ cells, respectively, whereas (Dose $x)_{1}$ and (Dose $\left.x\right)_{2}$ represent the dose of drug 1 (cisplatin) and drug 2 (NVP-BEZ235) in single drug treatment to inhibit $x \%$ cells, respectively. $\mathrm{CI}<1, \mathrm{CI}=1$ and $\mathrm{CI}>1$ indicated synergistic, additive and antagonistic effects of the combination therapy compared with single drug treatment, respectively.

Colony formation assay. A549/DDP cells were seeded $\left(5 \times 10^{2}\right.$ cells/well) in 6-well plates in triplicate, and cells were allowed to adhere overnight in a humidified atmosphere with $5 \% \mathrm{CO}_{2}$ at $37^{\circ} \mathrm{C}$. Cell media was replaced with drug-free fresh media (control), cisplatin $(1.53 \mu \mathrm{g} / \mathrm{ml})$, NVP-BEZ235 $(0.15 \mu \mathrm{g} / \mathrm{ml})$ or cisplatin + NVP-BEZ235 (cisplatin:NVP-BEZ235 at 10:1; cisplatin, $1.53 \mu \mathrm{g} / \mathrm{ml}$ ) and cells were incubated at $37^{\circ} \mathrm{C}$ for $24 \mathrm{~h}$. Subsequently, cell media was discarded and replaced with drug-free media. Adhered cells were cultured at $37^{\circ} \mathrm{C}$ for 7 days and fresh drug-free media was replaced every 2 days. At the indicated time points, cells were fixed in $70 \%$ ethanol for $10 \mathrm{~min}$ at $4^{\circ} \mathrm{C}$ and stained with Giemsa stain for $15 \mathrm{~min}$ at room temperature. Subsequently, colonies (clusters $>50$ cells) were observed and counted under a light microscope (magnification, $\mathrm{x} 40$; Olympus Corporation). The images presented in Fig. 3A were obtained using a digital camera.

Cell apoptosis (early + late apoptosis) analysis. A549/DDP cells were seeded $\left(2 \times 10^{6}\right.$ cells/well) into 6 -well plates in triplicate and allowed to adhere overnight in a humidified atmosphere with $5 \% \mathrm{CO}_{2}$ at $37^{\circ} \mathrm{C}$. Cell media was replaced with drug-free fresh media (control), cisplatin $(1.53 \mu \mathrm{g} / \mathrm{ml})$, NVP-BEZ235 $(0.15 \mu \mathrm{g} / \mathrm{ml})$, cisplatin + NVP-BEZ235 low dose (cisplatin:NVP-BEZ235 at 10:1; cisplatin, $1.53 \mu \mathrm{g} / \mathrm{ml}$ ) or cisplatin + NVP-BEZ235 high dose (cisplatin:NVP-BEZ235 at 10:1; cisplatin, $3.06 \mu \mathrm{g} / \mathrm{ml}$ ), and cells were incubated at $37^{\circ} \mathrm{C}$ for $24 \mathrm{~h}$. After incubation, cells were washed with PBS, collected and double stained with Annexin V-FITC and PI. The kit was used according to the manufacturer's protocol. Apoptotic cells were analyzed using a BD LSRFortessa flow cytometer (Becton Dickinson and Company) and Cell Quest software (version 5.2; Becton Dickinson and Company). A total of $1 \times 10^{4}$ cells were recorded for each sample. Data were analyzed using FlowJo software (VX10; Becton Dickinson and Company).
Table I. $\mathrm{IC}_{50}$ and IDR of cisplatin on A549/DDP cells ( $\mathrm{n}=3$ ).

\begin{tabular}{lcc}
\hline Cell & $\mathrm{IC}_{50}(\mu \mathrm{g} / \mathrm{ml})$ & $\mathrm{IDR}$ \\
\hline A549 & 1.36 & - \\
A549/DDP & 13.29 & 9.77 \\
\hline
\end{tabular}

IDR was calculated according to the following formula: $\mathrm{IDR}=\mathrm{IC}_{50}$ (A549/DDP) $/ \mathrm{IC}_{50(\mathrm{~A} 549)}$. IDR, index of drug resistance; $\mathrm{IC}_{50}$, half maximal inhibitory concentration; DDP, diamminedichloroplatinum resistance; -. not applicable.

Cell cycle analysis. A549/DDP cells were seeded $\left(2 \times 10^{6}\right.$ cells/well) into 6-well plates in triplicate and allowed to adhere overnight in a humidified atmosphere with $5 \% \mathrm{CO}_{2}$ at $37^{\circ} \mathrm{C}$. Cell media was replaced with drug-free fresh media (control), cisplatin $(1.53 \mu \mathrm{g} / \mathrm{ml})$, NVP-BEZ235 $(0.15 \mu \mathrm{g} / \mathrm{ml})$ or cisplatin + NVP-BEZ235 (cisplatin:NVP-BEZ235 at 10:1; cisplatin, $1.53 \mu \mathrm{g} / \mathrm{ml}$ ), and cells were incubated at $37^{\circ} \mathrm{C}$ for $24 \mathrm{~h}$. After incubation, cells were harvested via centrifugation $\left(1,000 \mathrm{x} \mathrm{g}, 4^{\circ} \mathrm{C}, 5 \mathrm{~min}\right)$ and washed with ice-cold PBS. Subsequently, cells were incubated with $25 \mu \mathrm{g} / \mathrm{ml}$ PI and $10 \mu \mathrm{g} / \mathrm{ml} \mathrm{RNase}$ for $30 \mathrm{~min}$ at room temperature in the dark room. The samples were analyzed using a BD LSRFortessa flow cytometer (Becton Dickinson and Company) and CellQuest software (version 5.2; Becton Dickinson and Company). A total of $1 \times 10^{4}$ cells were recorded for each sample. Data were analyzed using ModFit LT software(version 5.0; Verity Software House, Inc.).

Western blot analysis. A549/DDP cells were seeded $\left(2 \times 10^{6}\right.$ cells/well) into 6-well plates in triplicate and allowed to adhere overnight in a humidified atmosphere with $5 \% \mathrm{CO}_{2}$ at $37^{\circ} \mathrm{C}$. Cell media was replaced with drug-free fresh media (control), cisplatin $(1.53 \mu \mathrm{g} / \mathrm{ml})$, NVP-BEZ235 $(0.15 \mu \mathrm{g} / \mathrm{ml})$ or cisplatin + NVP-BEZ235 (cisplatin:NVP-BEZ235 at 10:1; cisplatin, $1.53 \mu \mathrm{g} / \mathrm{ml}$ ), and incubated at $37^{\circ} \mathrm{C}$ for $24 \mathrm{~h}$. After incubation, cells were washed with PBS and lysed with RIPA lysis buffer (Beyotime Institute of Biotechnology), containing $1 \mathrm{mM}$ PMSF (Beyotime Institute of Biotechnology) and phosphatase inhibitor (1 tablet dissolved in $10 \mathrm{ml}$ RIPA lysis buffer; Roche Diagnostics $\mathrm{GmbH})$. Total protein was quantified using the BCA protein Assay kit. Equal amounts of proteins $(20 \mu \mathrm{g}$ protein/lane) were separated via $8 \%$ SDS-PAGE and transferred onto PVDF membranes. Subsequently, the membranes were blocked in tris-buffered saline with $0.1 \%$ Tween-20 (TBS-T) buffer solution containing 5\% skimmed milk for $2 \mathrm{~h}$ at room temperature, followed by washing with TBS-T a further three times. The membranes were incubated with primary antibodies, including antibodies targeted against Akt, p-Akt, p70S6K, p-p70S6K, ABCG2, MRP1 and $\beta$-actin, overnight at $4^{\circ} \mathrm{C}$. The membranes were washed with TBS-T and then incubated with a HRP-labeled goat anti-rabbit IgG secondary antibody for $1 \mathrm{~h}$ at room temperature. Protein bands were visualized using a Fusion FX7Spectra enhanced chemiluminescence system (Vilber Lourmat Deutschland $\mathrm{GmbH}$ ). The intensity of the bands was semi-quantified using ImageJ software (1.48v; National Institutes of Health) with $\beta$-actin as the loading control. 
A
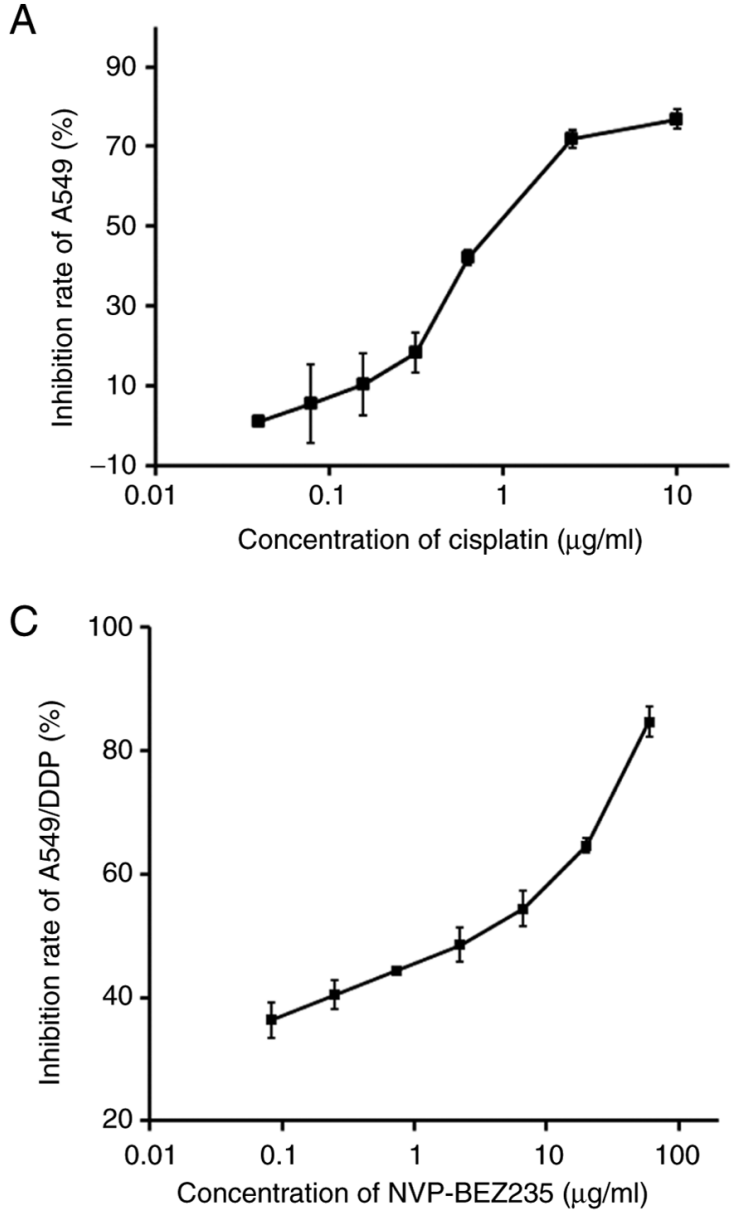

B

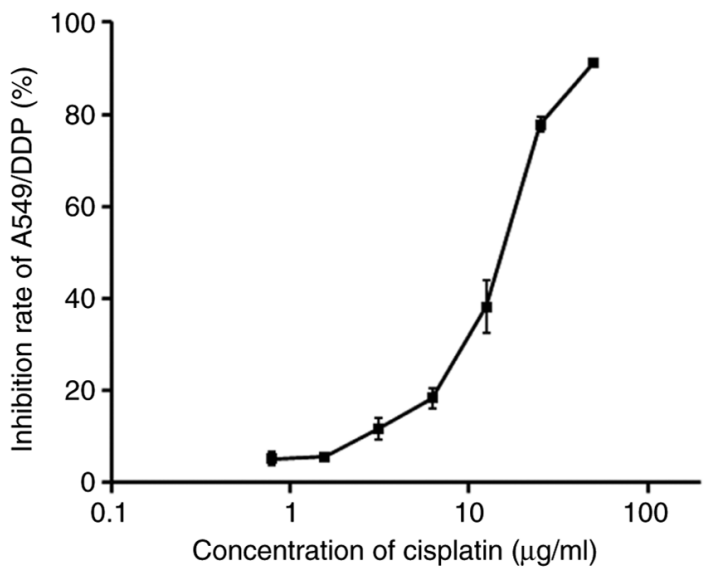

D

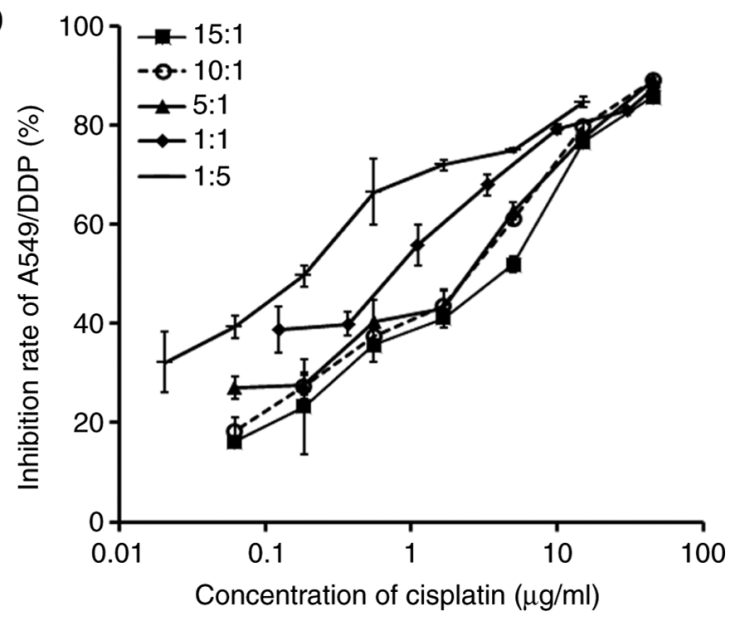

Figure 1. Co-treatment of cisplatin and NVP-BEZ235 synergistically inhibits A549/DDP cell proliferation. (A) Inhibition rates of A549 cells after treatment with cisplatin for $48 \mathrm{~h}$. Inhibition rates of A549/DDP cells after treatment with (B) cisplatin, (C) NVP-BEZ235 and (D) different mass ratios (15:1, 10:1, 5:1, 1:1 or 1:5) of cisplatin and NVP-BEZ235 for $48 \mathrm{~h}$. Data are presented as the mean \pm standard deviation $(\mathrm{n}=3)$. DDP, diamminedichloroplatinum resistance.

Statistical analysis. All experiments were performed in triplicate. Data are presented as the mean \pm SD. Statistical analyses were preformed using SPSS software (version 21; IBM Corp). Comparisons among multiple groups were analyzed using one-way analysis of variance followed by Bonferroni's post hoc test. $\mathrm{P}<0.05$ was considered to indicate a statistically significant difference.

\section{Results}

Co-treatment of cisplatin and NVP-BEZ235 synergistically inhibits A549/DDP cell proliferation. A CCK-8 assay kit was used to evaluate the antiproliferative effects of cisplatin and NVP-BEX235. The effects of cisplatin, NVP-BEZ235 and combinations of cisplatin and NVP-BEZ235 with different mass ratios $(15: 1,10: 1,5: 1,1: 1$ or $1: 5)$ on A549/DDP cells were tested. The inhibitory effects of cisplatin on A549 and A549/DDP cells were dose-dependent (Fig. 1A and B). The half maximal inhibitory concentration $\left(\mathrm{IC}_{50}\right)$ of cisplatin on A549 cells was $1.36 \mu \mathrm{g} / \mathrm{ml}$ (Table I). The $\mathrm{IC}_{50}$ of cisplatin on A549/DDP cells was $13.29 \mu \mathrm{g} / \mathrm{ml}$. A549/DDP cells displayed strong resistance to cisplatin treatment and the index of drug resistance (IDR) of cisplatin on A549/DDP cells was 9.77. IDR was calculated using the following formula: $\mathrm{IDR}=\mathrm{IC}_{50}(\mathrm{~A} 549 / \mathrm{DDP}) / \mathrm{IC}_{50}(\mathrm{~A} 549)$, as presented in Table I.
CI was adopted to evaluate whether combiantion treatment of cisplatin and NVP-BEZ235 had synergistic $(\mathrm{CI}<1)$, additive $(C I=1)$ or antagonistic $(C I>1)$ effects on A549/DDP cells. The $\mathrm{IC}_{50}$ of NVP-BEZ235 was $1.33 \mu \mathrm{g} / \mathrm{ml}$, which indicated apparent toxicity on A549/DDP cells (Fig. 1C and Table II). A total of five different mass ratios of cisplatin and NVP-BEZ235 were used to test the combinatorial effects of cisplatin and NVP-BEZ235 on A549/DDP cells, and the results are presented in Fig. 1D and Table II. The CI values were between 0.2-0.7, which indicated a synergistic effect. A dose-normalized isobologram for the two drugs was constructed (Fig. 2). Cisplatin and NVP-BEZ235 displayed the strongest synergy $\left(\mathrm{CI}_{50}=0.23\right)$ when they were delivered at a mass ratio of 10:1. The concentrations of cisplatin and NVP-BEZ235 were 1.53 and $0.15 \mu \mathrm{g} / \mathrm{ml}$, respectively.

Co-treatment of cisplatin and NVP-BEZ235 inhibits A549/DDP cell colony formation. A549 cells were incubated with cisplatin $(1.53 \mu \mathrm{g} / \mathrm{ml})$, NVP-BEZ235 $(0.15 \mu \mathrm{g} / \mathrm{ml})$ or cisplatin + NVP-BEZ235 (cisplatin:NVP-BEZ235 at 10:1; cisplatin, $1.53 \mu \mathrm{g} / \mathrm{ml}$ ) for $24 \mathrm{~h}$. Subsequently, cell media was discarded and adherent cells were cultured in fresh media for 7 days for colony formation. Clusters of $>50$ cells were considered as valid colonies (Fig. 3A). The number of colonies for each group was counted (Fig. 3B). The number of colonies 
Table II. Concentrations of cisplatin and NVP-BEZ235 at a 50\% inhibition rate against A549/DDP cells for different mass ratios and the corresponding $\mathrm{CI}(\mathrm{n}=3)$.

\begin{tabular}{lccr}
\hline Treatment & $\begin{array}{c}\text { Concentration of cisplatin } \\
(\mu \mathrm{g} / \mathrm{ml})\end{array}$ 50\% inhibition & $\begin{array}{c}\text { Concentration of NVP-BEZ235 } \\
(\mu \mathrm{g} / \mathrm{ml}) \text { 50\% inhibition }\end{array}$ & $\mathrm{CI}_{50}$ \\
\hline Cisplatin & 13.29 & - & - \\
NVP-BEZ235 & - & 1.33 & - \\
Cisplatin:NVP-BEZ235 at 15:1 & 2.23 & 0.15 & 0.28 \\
Cisplatin:NVP-BEZ235 at 10:1 & 1.53 & 0.15 & 0.23 \\
Cisplatin:NVP-BEZ235 at 5:1 & 1.28 & 0.26 & 0.29 \\
Cisplatin:NVP-BEZ235 at 1:1 & 0.58 & 0.58 & 0.48 \\
Cisplatin:NVP-BEZ235 at 1:5 & 0.16 & 0.79 & 0.61 \\
\hline
\end{tabular}

CI, combination index; DDP, diamminedichloroplatinum resistance; -, not applicable.

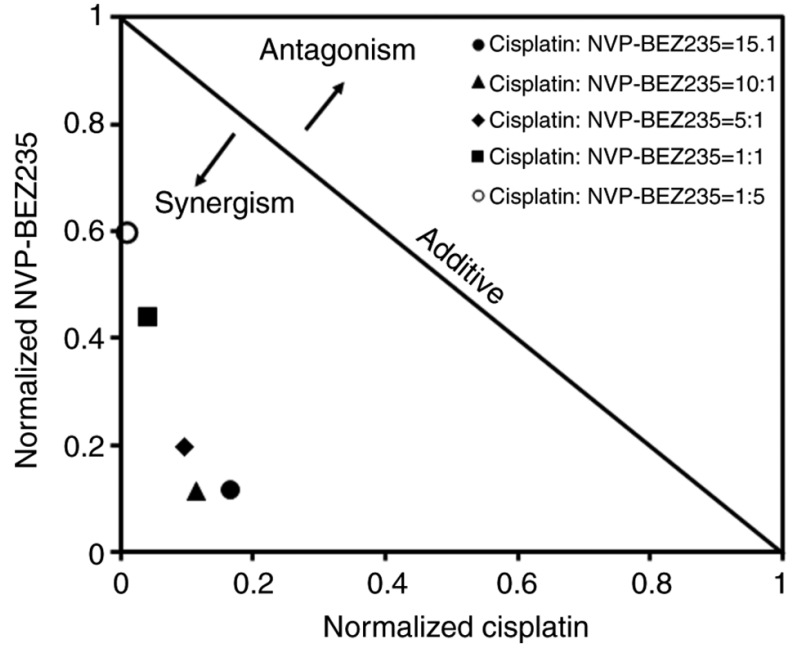

Figure 2. Dose-normalized isobologram for cisplatin and NVP-BEZ235. Scores $<1$ indicate a synergistic effect, scores of 1 indicate an additive effect and scores $>1$ indicate an antagonistic effect. NVP-BEZ235 and cisplatin were used at the stated ratios.

was significantly reduced $(\mathrm{P}<0.001)$ in drug-treated groups compared with the control group, which indicated that both cisplatin and NVP-BEZ235 inhibited A549/DDP cell colony formation. Specifically, compared with the cisplatin group, combined treatment of cisplatin and NVP-BEZ235 displayed further inhibitory effects on colony formation, as indicated by a reduced number of colonies.

Co-treatment of cisplatin and NVP-BEZ235 induces A549/DDP cell apoptosis. A549/DDP cells were incubated with cisplatin $(1.53 \mu \mathrm{g} / \mathrm{ml}), \mathrm{NVP}-\mathrm{BEZ} 235(0.15 \mu \mathrm{g} / \mathrm{ml})$ or cisplatin + NVP-BEZ235 (low or high dose) for $24 \mathrm{~h}$. Cell apoptosis assays were performed using the Annexin V-FITC/PI double staining method. Q2, Q3 and Q4 represented different stages of the cell cycle (Fig. 4A-E). Q2 and Q3 indicate late and early cell apoptosis, respectively, and the total apoptosis rates were the sum of Q2 and Q3 (Fig. 4F). Apoptosis rates were significantly increased in the cisplatin $(\mathrm{P}<0.05)$, NVP-BEZ235 $(\mathrm{P}<0.001)$ and cisplatin + NVP-BEZ235 (low or high dose; $\mathrm{P}<0.001)$ groups compared with the control group. Specifically, the cisplatin + NVP-BEZ235 (high dose) group displayed significantly increased apoptotic rates compared with the cisplatin group. The results indicated that NVP-BEZ235 induced A549/DDP cell apoptosis and a combination of cisplatin and NVP-BEZ235 further increased A549/DDP cell apoptosis.

Co-treatment of cisplatin and NVP-BEZ235 induces cell cycle arrest at the $G_{0} G_{1}$ phase. A549/DDP cells were incubated with cisplatin $(1.53 \mu \mathrm{g} / \mathrm{ml})$, NVP-BEZ235 $(0.15 \mu \mathrm{g} / \mathrm{ml})$ and cisplatin + NVP-BEZ235 (cisplatin:NVP-BEZ235 at 10:1; cisplatin, $1.53 \mu \mathrm{g} / \mathrm{ml}$ ) for $24 \mathrm{~h}$ and analysis of the cell cycle distribution was conducted via flow cytometry. $G_{0} G_{1}, G_{2} M$ and $\mathrm{S}$ phases were analyzed separately (Fig. 5A-E). The number of cells in the $G_{0} G_{1}$ phase was increased significantly in the NVP-BEZ235 $(\mathrm{P}<0.001)$ and cisplatin + NVP-BEZ235 $(\mathrm{P}<0.001)$ groups compared with the control group. The number of cells in the $\mathrm{G}_{2} \mathrm{M}$ and $\mathrm{S}$ phases was decreased significantly in the cisplatin + NVP-BEZ235 $(\mathrm{P}<0.001)$ group compared with the control group. The results indicated that combined treatment of NVP-BEZ235 and cisplatin could induce cell cycle arrest at the $\mathrm{G}_{0} \mathrm{G}_{1}$ phase.

Co-treatment of cisplatin and NVP-BEZ235 reduced the phosphorylation of Akt and S6K protein. Western blot analysis of A549/DDP cells incubated with cisplatin $(1.53 \mu \mathrm{g} / \mathrm{ml})$, NVP-BEZ235 $(0.15 \mu \mathrm{g} / \mathrm{ml})$ and cisplatin + NVP-BEZ235 (cisplatin:NVP-BEZ235 at 10:1, cisplatin: $1.53 \mu \mathrm{g} / \mathrm{ml}$ ) for $24 \mathrm{~h}$ was conducted (Fig. 6A). The relative protein expression levels were then analyzed and normalized to the expression levels of $\beta$-actin. The expression levels of $\mathrm{p}$-Akt and $\mathrm{p}-\mathrm{S} 6 \mathrm{~K}$ were further normalized to the expression levels of total Akt and S6K (Fig. 6B). Cisplatin treatment alone $(1.53 \mu \mathrm{g} / \mathrm{ml})$ did not significantly alter the expression of $\mathrm{p}$-Akt or $\mathrm{p}-\mathrm{S} 6 \mathrm{~K}$ compared with the control group (Fig. 6). Cisplatin treatment did not inhibit the PI3K/Akt/mTOR signalling pathways. Compared with the control and cisplatin groups, NVP-BEZ235, a dual PI3K/Akt and mTOR inhibitor, decreased the expression levels of $\mathrm{p}-\mathrm{Akt}$ and p-S6K $(\mathrm{P}<0.05)$ and inhibited the PI3K/Akt/mTOR signalling pathway, which suggests that NVP-BEZ235 may inhibit tumour growth. However, the NVP-BEZ235 + cisplatin group did not further reduce the phosphorylation of Akt and S6K 


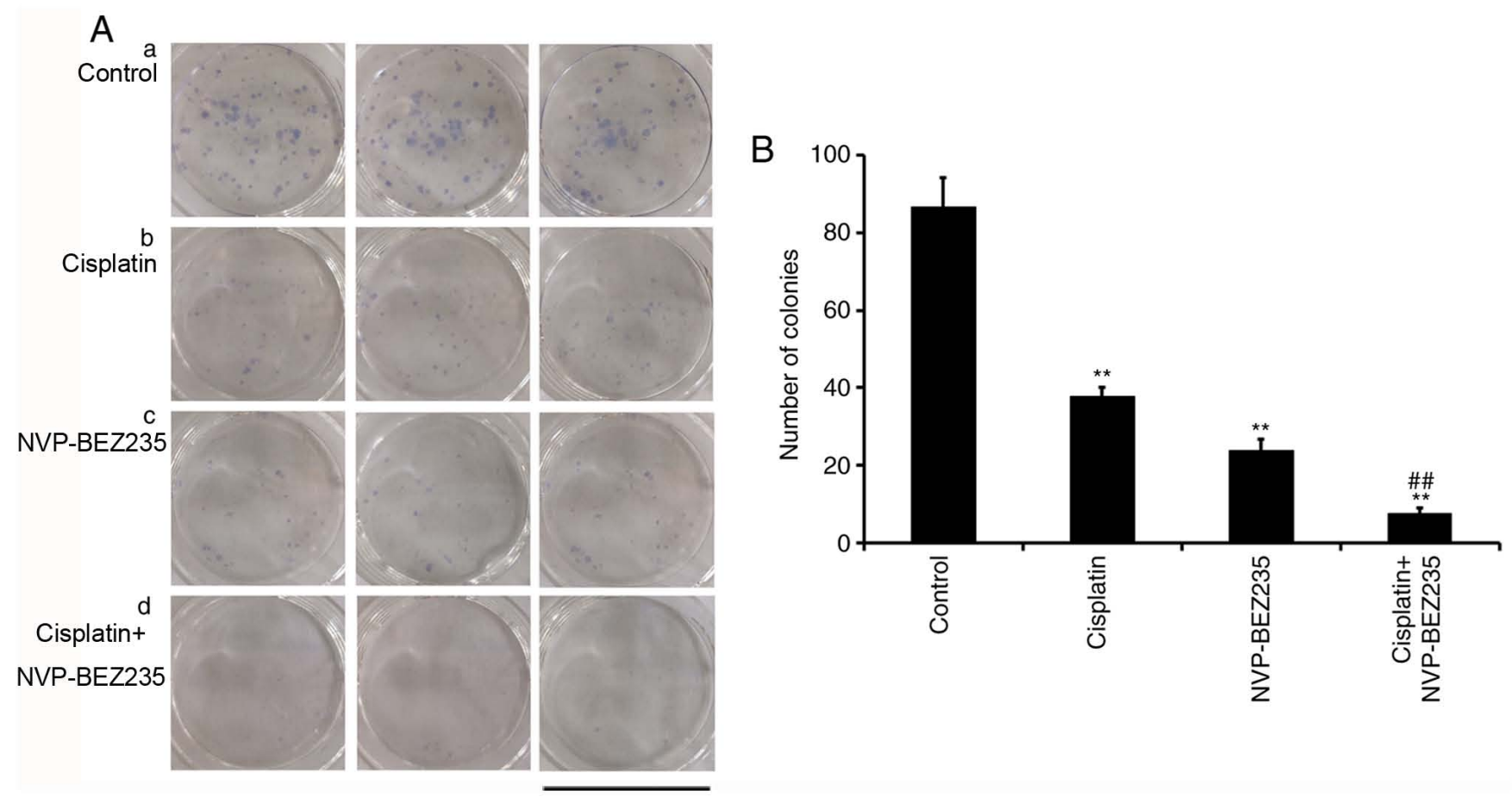

Figure 3. Co-treatment of cisplatin and NVP-BEZ235 synergistically inhibits A549/DDP cell colony formation. (A) A colony formation assay was performed a, control; b, cisplatin (1.53 $\mu \mathrm{g} / \mathrm{ml})$; c, NVP-BEZ235 (0.15 $\mu \mathrm{g} / \mathrm{ml})$; d, cisplatin+NVP-BEZ235 (cisplatin: NVP-BEZ235 at 10:1, cisplatin: 1.53 $\mu \mathrm{g} / \mathrm{ml})$. (B) The number of colonies of A549/DDP cells was quantified after different treatment.Scale bar, $34.8 \mathrm{~mm}$. Data are presented as the mean \pm standard deviation $(\mathrm{n}=3)$. ${ }^{* *} \mathrm{P}<0.001$ vs. control group; ${ }^{\# \#} \mathrm{P}<0.001$ vs. cisplatin group. DDP, diamminedichloroplatinum resistance.
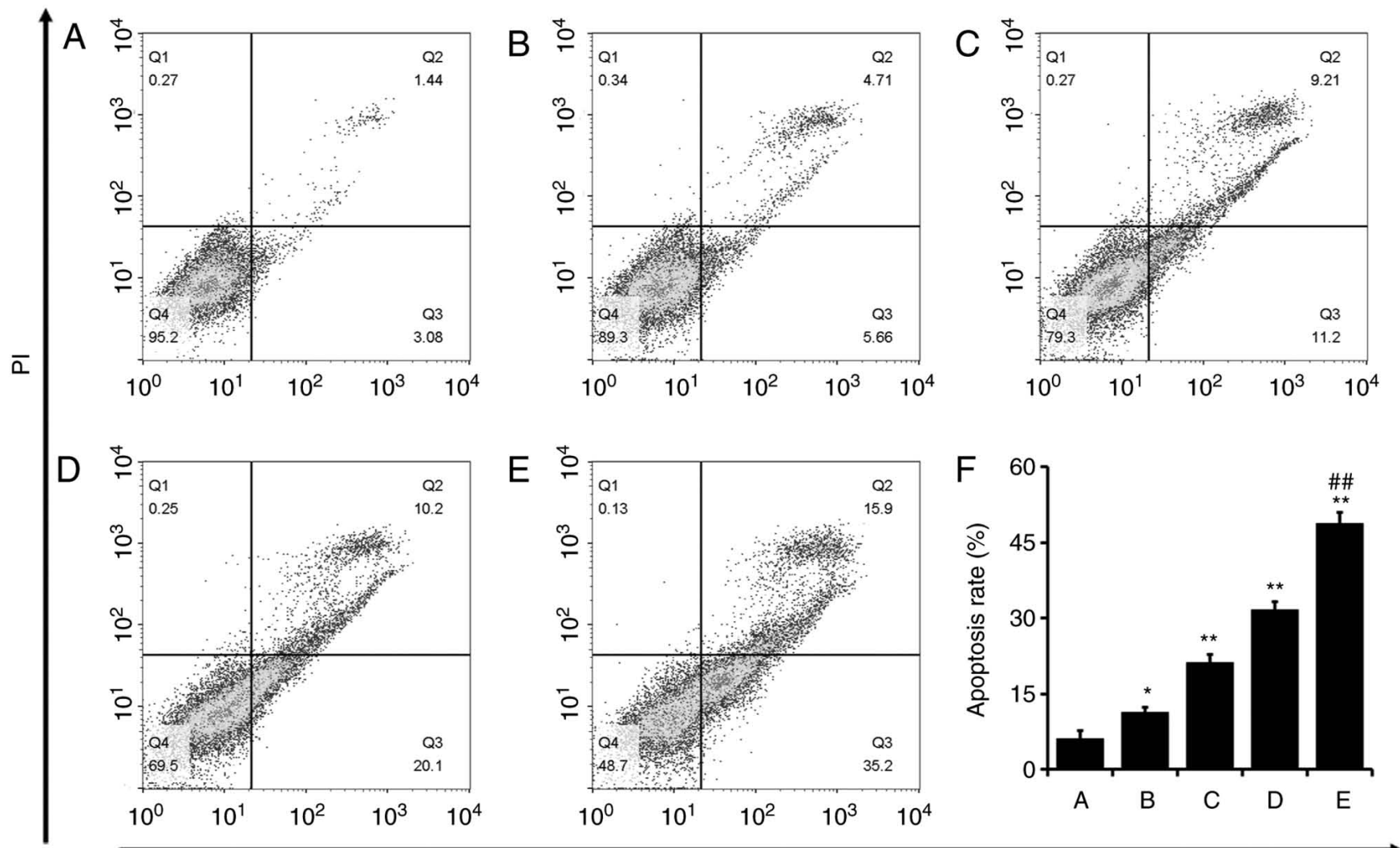

Annexin V-FITC

Figure 4. Co-treatment of cisplatin and NVP-BEZ235 synergistically induces A549/DDP cell apoptosis. A549/DDP cell apoptosis following treatment with (A) control, (B) cisplatin (1.53 $\mu \mathrm{g} / \mathrm{ml})$, (C) NVP-BEZ235 (0.15 $\mu \mathrm{g} / \mathrm{ml})$, (D) cisplatin + NVP-BEZ235 low dose (cisplatin:NVP-BEZ235 at 10:1; cisplatin, $1.53 \mu \mathrm{g} / \mathrm{ml}$ ) or (E) cisplatin + NVP-BEZ235 high dose (cisplatin:NVP-BEZ235 at 10:1; cisplatin, $3.06 \mu \mathrm{g} / \mathrm{ml}$ ) for $24 \mathrm{~h}$. (F) Quantification of the rate of apoptosis. Data are presented as the mean \pm standard deviation $(\mathrm{n}=3) .{ }^{*} \mathrm{P}<0.05$ and ${ }^{* *} \mathrm{P}<0.001$ vs. control group; ${ }^{\# *} \mathrm{P}<0.001$ vs. cisplatin group. DDP, diamminedichloroplatinum resistance. 

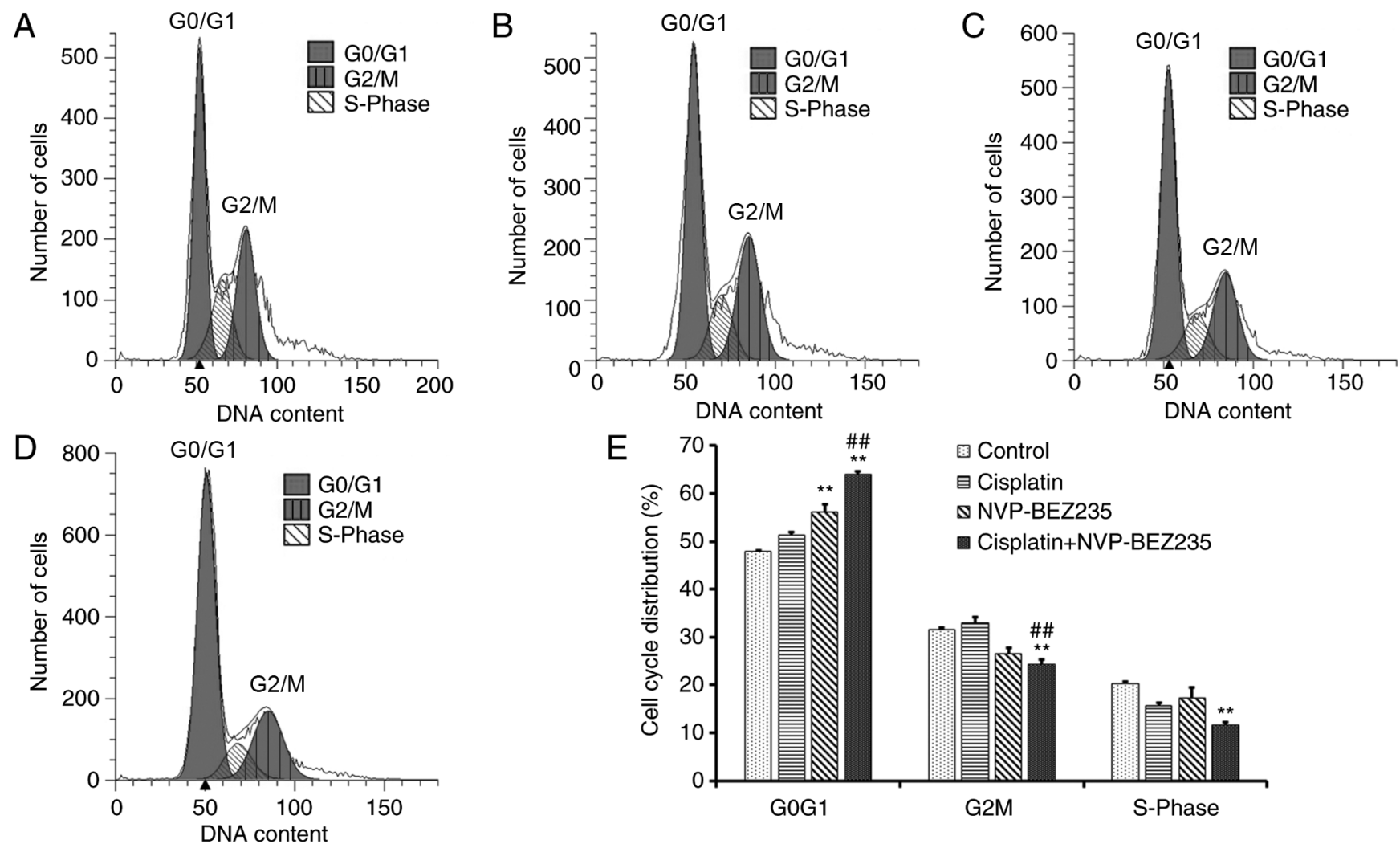

Figure 5. Co-treatment of cisplatin and NVP-BEZ235 induces cell cycle arrest at the $\mathrm{G}_{0} \mathrm{G}_{1}$ phase. Cell cycle distribution of A549/DDP cells following treatment with (A) control, (B) cisplatin (1.53 $\mu \mathrm{g} / \mathrm{ml})$, (C) NVP-BEZ235 (0.15 $\mu \mathrm{g} / \mathrm{ml})$ or (D) cisplatin + NVP-BEZ235 (cisplatin:NVP-BEZ235 at 10:1; cisplatin, $1.53 \mu \mathrm{g} / \mathrm{ml}$ ) for $24 \mathrm{~h}$. (E) Quantification of the cell cycle distribution. Data are presented as the mean \pm standard deviation $(\mathrm{n}=3)$. ${ }^{* *} \mathrm{P}<0.001 \mathrm{vs}$. control group; ${ }^{\# \#} \mathrm{P}<0.001$ vs. cisplatin group. DDP, diamminedichloroplatinum resistance.

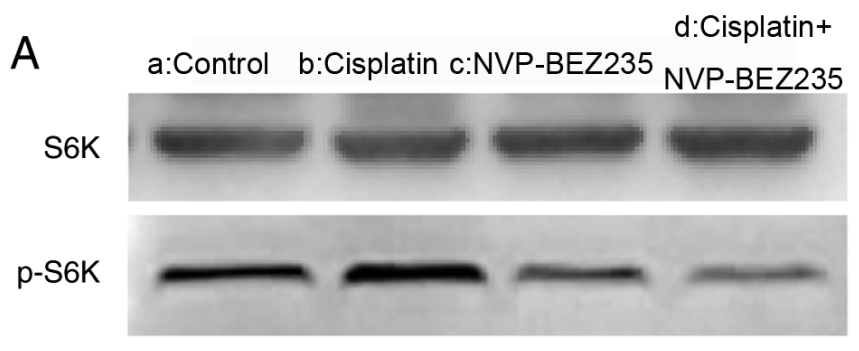

Akt

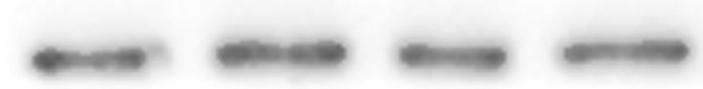

p-Akt

$\beta$-actin
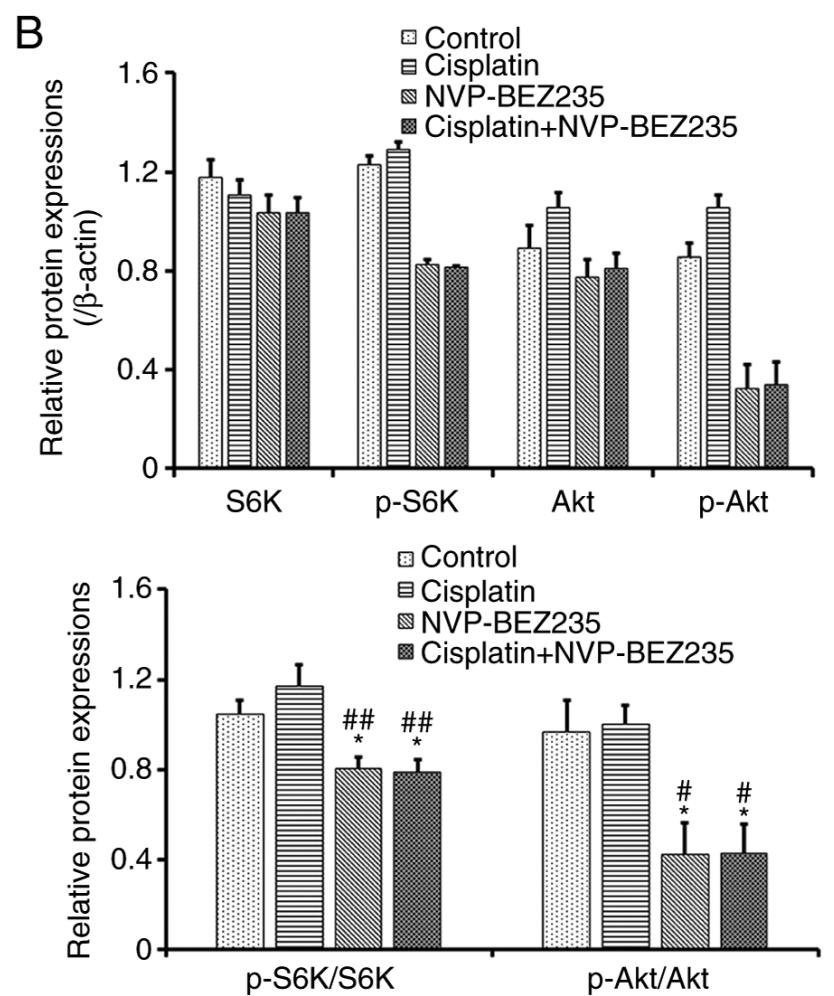

Figure 6. Co-treatment of cisplatin and NVP-BEZ235 reduces the phosphorylation of Akt and S6K protein. (A) Western blotting was performed to assess protein expression levels in A549/DDP cells following treatment for $24 \mathrm{~h}$ with: a, control; b, cisplatin (1.53 $\mu \mathrm{g} / \mathrm{ml}) ; \mathrm{c}, \mathrm{NVP}-\mathrm{BEZ} 235$ (0.15 $\mu \mathrm{g} / \mathrm{ml})$; or d, cisplatin + NVP-BEZ235 (cisplatin:NVP-BEZ235 at 10:1; cisplatin, $1.53 \mu \mathrm{g} / \mathrm{ml}$ ). (B) Semi-quantification of protein expression levels. Data are presented as the mean \pm standard deviation $(n=3)$. ${ }^{*} \mathrm{P}<0.05$ vs. control group; ${ }^{*} \mathrm{P}<0.05$ and ${ }^{\# \#} \mathrm{P}<0.001$ vs. cisplatin group. DDP, diamminedichloroplatinum resistance; p, phosphorylated; S6K, S6 Kinase. 

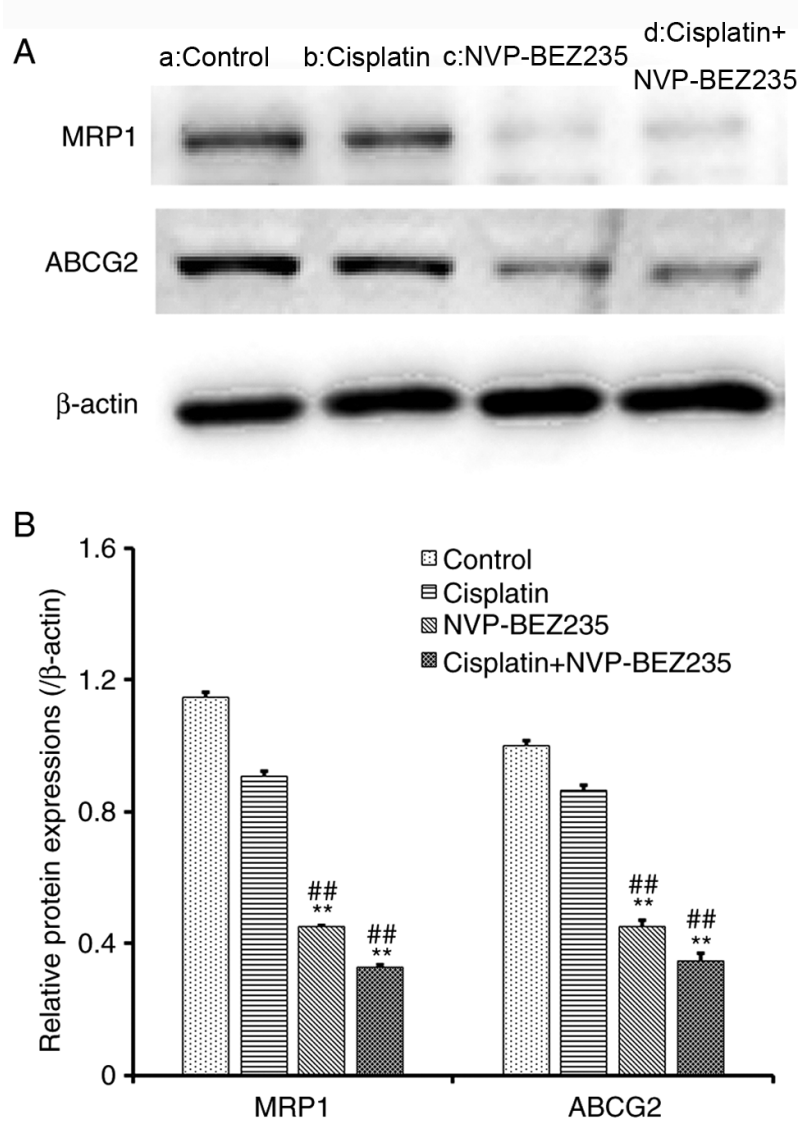

Figure 7. Co-treatment of cisplatin and NVP-BEZ235 reduces the expression of drug efflux proteins. (A) Western blotting was performed to assess protein expression levels in A549/DDP cells following treatment for $24 \mathrm{~h}$ with: a, control; b, cisplatin $(1.53 \mu \mathrm{g} / \mathrm{ml})$; c, NVP-BEZ235 $(0.15 \mu \mathrm{g} / \mathrm{ml})$ or d, cisplatin + NVP-BEZ235 (cisplatin:NVP-BEZ235 at 10:1; cisplatin $1.53 \mu \mathrm{g} / \mathrm{ml}$ ). (B) Semi-quantification of protein expression levels. Data are presented as the mean \pm standard deviation $(\mathrm{n}=3) .{ }^{* *} \mathrm{P}<0.001$ vs. control group; ${ }^{\# \#} \mathrm{P}<0.001$ vs. cisplatin group. MRP1, multidrug resistance-associated protein 1; ABCG2, ATP-binding cassette sub-family G member 2; DDP, diamminedichloroplatinum resistance.

compared with NVP-BEZ235 treatment alone. The results indicated that NVP-BEZ235 might display antiproliferative effects on A549/DDP cells via inhibition of the PI3K/Akt and mTOR signaling pathways.

Co-treatment of cisplatin and NVP-BEZ235 reduced the expression of drug efflux proteins. The expression levels of the ABC binding cassette transporter proteins MRP1 and ABCG2 in A549/DDP cells were further investigated via western blot analysis (Fig. 7A-B). Cells exposed to NVP-BEZ235 alone or combined treatment of cisplatin and NVP-BEZ235 displayed significantly reduced protein expression levels of MRP1 and ABCG2 compared with the control and cisplatin groups. The results suggested that NVP-BEZ235 might reverse the drug resistance of NSCLC cells by inhibiting the drug efflux protein, leading to drug accumulation in A549/DDP cells and more toxic effects.

\section{Discussion}

At present, lung cancer remains a great threat to people's health, especially NSCLC, which accounts for $75-80 \%$ of lung cancers (32). However, the outcomes of standard chemotherapy for NSCLC is poor, and numerous factors contribute to treatment failure and subsequent death $(2,3)$. Among those factors, drug resistance is the major cause of treatment failure. Increasing the dose of chemotherapeutic agents has minimal therapeutic effects but serves to also increase the side effects of chemotherapeutics $(11,12)$. Co-delivering two or more different types of chemotherapeutics has been an effective strategy for various cancer treatments, even for drug-resistant or metastatic cancerous tumors (33). Two or more chemotherapeutics have been reported to be able to synergistically kill cancer cells at lower doses and reduce severe systemic side effects (29,34-36).

Cisplatin, a platinum-based chemotherapeutic drug widely used in lung cancer treatment, is commonly resistant in patients with lung cancer after several cycles of chemotherapy (7). To reduce the side effects, such as severe renal injury, a number of chemotherapeutics have been used in combination with cisplatin to reduce the single dose of chemotherapeutics $(6,37)$. The present study selected a novel dual PI3K/Akt/mTOR inhibitor, NVP-BEZ235, to chemosensitize the toxicity of cisplatin. By contrast to the high resistance of cisplatin, the toxicity of NVP-BEZ235 towards drug-resistant A549/DDP cells was apparent and the $\mathrm{IC}_{50}$ value was found to be only $1.33 \mu \mathrm{g} / \mathrm{ml}$. The relationship between cisplatin and NVP-BEZ235 was further investigated regarding the antiproliferative effects on A549/DDP cells. The results indicated that there was a strong synergism of two drugs as all the CI values were $<1$ and the subsequent colony formation assays and apoptosis assays were consistent with the antiproliferation assays. The strongest synergy was demonstrated when cisplatin and NVP-BEZ235 were delivered at a mass ratio of $10: 1$, with a $\mathrm{CI}_{50}$ of 0.23 . Therefore, this mass ratio was adopted for the further investigation of cisplatin and NVP-BEZ235 on A549/DDP cells.

It has been widely accepted that upregulation of the PI3K/Akt/mTOR signalling pathway has been associated with drug resistance and the inhibition of apoptosis in various tumours (17-22). So, the selection of specific kinase inhibitors might be an approach to overcome drug resistance and induce cell apoptosis. In the present research, NVP-BEZ235, a dual PI3K/Akt/mTOR inhibitor was selected to evaluate the synergistic effect on A549/DDP cells. The PI3K/Akt/mTOR pathway is activated by the phosphorylation of Akt and related downstream proteins. Phosphorylation of Akt protein activates mTOR complex (mTORC)1 and subsequently induces the phosphorylation of p70S6K. mTORC2, has also been identified to serve as a feedback loop via Akt $(9,19)$. Activation of mTORC2 via phosphorylated S6K induces phosphorylation of Akt, thereby inhibiting mTORC1 activation (38). The results of the western blot analysis indicated that addition of NVP-BEZ235 significantly reduced the phosphorylation of Akt and S6K protein compared with the control and cisplatin groups. S6K protein is a downstream signalling regulator of $\mathrm{PI} 3 \mathrm{~K} / \mathrm{Akt} / \mathrm{mTOR}$ signalling pathway and its reduction indicates the reduced expression of mTOR $(9,19,38)$. The results suggested that NVP-BEZ235 might reverse drug resistance and induce cell apoptosis via inhibition of the PI3K/Akt/mTOR signalling pathway, though complete regulation and potential feedback loops require further investigation, such as the 
expression of mTORC1, mTORC2 and their phosphorylated forms.

Previous research has indicated that NVP-BEZ235 could regulate the expression of plasma membrane-associated proteins, such as cadherin (39). However, whether NVP-BEZ235 could regulate the expression of ABC transporters on cancer cell membranes has not been investigated. The ABC transporters are drug efflux proteins that can pump drug molecules out of cancer cells in an ATP-dependent manner (11). Among the ABC transporter superfamily, ABCB1 (P-glycoprotein), MRP1 and ABCG2 are the most expressed on cancer cell membranes $(8,9)$. The present study indicated that NVP-BEZ235 not only inhibited the PI3K/Akt/mTOR pathway, but also decreased the expression of MRP1 and ABCG2 in A549/DDP cells compared with the cisplatin and control groups. The results indicated that NVP-BEZ235 might be a drug efflux pump inhibitor and promote the accumulation of chemotherapeutic agents in drug-resistant cancer cells.

Nevertheless, further studies are required to confirm the hypothesis stated here, such as the intracellular accumulation of cisplatin and the mRNA expression levels of the associated proteins. In addition, the lack of analysis of cell proliferation-associated pathways, with respect to the combination treatment was a limitation of the present study. Furthermore, suppressing PI3K and mTOR expression in A549/DDP cells to assess the inhibitory rates of dual drug treatments on cell proliferation would be a good extension for prospective studies. Overall, the present study suggested that co-treatment of cisplatin and NVP-BEZ235 synergistically killed cisplatin-resistant cancer A549/DDP cells via inhibition of the PI3K/Akt/mTOR pathway and drug efflux proteins, MRP1 and ABCG2. Moreover, co-treatment induced cell cycle arrest at the $G_{0} G_{1}$ phase and ultimately led to cell death. In summary, the present study indicated that combined treatment of cisplatin and NVP-BEZ235 exerted strong synergistic effects on drug-resistant A549/DDP cells in vitro. The antiproliferative effect may occur via inhibition of the $\mathrm{PI} 3 \mathrm{~K} / \mathrm{Akt} / \mathrm{mTOR}$ signaling pathway and downregulation of the expression levels of drug efflux proteins, such as MRP1 and ABCG2. Combination therapy also induced cell arrest at the $\mathrm{G}_{0} \mathrm{G}_{1}$ phase, and ultimately induced cell apoptosis and cell death. However, further in vivo studies are required to verify the results of the present study. The results of the present study may aid with the development of novel therapeutic strategies for patients with advanced NSCLC.

\section{Acknowledgements}

Not applicable.

\section{Funding}

The present study was funded by the Seed Founding of Shanghai Ninth People's Hospital, Shanghai Jiao Tong University School of Medicine (grant no. JYZZ063), the Clinical Pharmacy Innovation Research Institute of Shanghai Jiao Tong University School of Medicine (2019; grant nos. CXYJY2019MS002 and CXYJY2019QN002) and the Shanghai Key Specialty Project of Clinical Pharmacy, Shanghai, China.

\section{Availability of data and materials}

The datasets used and/or analyzed during the present study are available from the corresponding author upon reasonable request.

\section{Authors' contributions}

HZ, RW and YY designed the whole experiment. HZ, YS and XJ performed the experiments. HZ, YS, XJ and GY analyzed the data. HZ wrote the first draft of the manuscript. GY, RW and YY revised the manuscript critically. All authors read and approved the final manuscript.

\section{Ethics approval and consent to participate}

Not applicable.

\section{Patient consent for publication}

Not applicable.

\section{Competing interests}

The authors declare that they have no competing interests.

\section{References}

1. Bray F, Ferlay J, Soerjomataram I, Siegel RL, Torre LA and Jemal A: Global cancer statistics 2018: GLOBOCAN estimates of incidence and mortality worldwide for 36 cancers in 185 countries. CA Cancer J Clin 68: 394-424, 2018.

2. Reck M and Rabe KF: Advanced non-small-cell lung cancer. N Engl J Med 377: 1999, 2017.

3. Herbst RS, Morgensztern D and Boshoff C: The biology and management of non-small cell lung cancer. Nature 553: 446-454, 2018.

4. Du L, Waqar SN and Morgensztern D: Multimodality therapy for NSCLC. Cancer Treat Res 170: 151-163, 2016.

5. Sgambato A, Casaluce F, Maione P and Gridelli C: Targeted therapies in non-small cell lung cancer: A focus on ALK/ROS1 tyrosine kinase inhibitors. Expert Rev Anticancer Ther 18: 71-80, 2018.

6. Dasari S and Tchounwou PB: Cisplatin in cancer therapy: Molecular mechanisms of action. Eur J Pharmacol 740: 364-378, 2014.

7. Arbour KC and Riely GJ: Systemic therapy for locally advanced and metastatic non-small cell lung cancer: A review. JAMA 322: 764-774, 2019.

8. Fennell DA, Summers Y, Cadranel J, Benepal T, Christoph DC, Lal R, Das M, Maxwell F, Visseren-Grul C and Ferry D: Cisplatin in the modern era: The backbone of first-line chemotherapy for non-small cell lung cancer. Cancer Treat Rev 44: 42-50, 2016.

9. Fumarola C, Bonelli MA, Petronini PG and Alfieri RR: Targeting PI3K/AKT/mTOR pathway in non small cell lung cancer. Biochem Pharmacol 90: 197-207, 2014.

10. Durrant DE, Das A, Dyer S, Tavallai S, Dent P and Kukreja RC: Targeted inhibition of phosphoinositide 3-kinase/mammalian target of rapamycin sensitizes pancreatic cancer cells to doxorubicin without exacerbating cardiac toxicity. Mol Pharmacol 88: 512-523, 2015.

11. Amawi H, Sim HM, Tiwari AK, Ambudkar SV and Shukla S: $\mathrm{ABC}$ transporter-mediated multidrug-resistant cancer. Adv Exp Med Biol 1141: 549-580, 2019.

12. Robey RW, Pluchino KM, Hall MD, Fojo AT, Bates SE and Gottesman MM: Revisiting the role of ABC transporters in multidrug-resistant cancer. Nat Rev Cancer 18: 452-464, 2018.

13. Babichev Y, Kabaroff L, Datti A, Uehling D, Isaac M, Al-Awar R, Prakesch M, Sun RX, Boutros PC, Venier R, et al: PI3K/AKT/mTOR inhibition in combination with doxorubicin is an effective therapy for leiomyosarcoma. J Transl Med 14: 67, 2016. 
14. Zucali PA, Perrino M, De Vincenzo F, Giordano L, Cordua N, D'Antonio F and Santoro A: A phase II study of the combination of gemcitabine and imatinib mesylate in pemetrexed-pretreated patients with malignant pleural mesothelioma. Lung Cancer 142: 132-137, 2020.

15. Cao W, Yang Q, Yuan Z, Li H, Wang W, Xiao X, Wang Z, Liang L, Zhou P, Liu J, et al: Gemcitabine inhibits cisplatin resistance in cisplatin-resistant A549 cells by upregulating trx-interacting protein and inducing cell cycle arrest. Biochem Biophys Res Commun 524: 549-554, 2020.

16. Zhou M, Zheng J, Bi J, Wu X, Lyu J and Gao K: Synergistic inhibition of colon cancer cell growth by a combination of atorvastatin and phloretin. Oncol Lett 15: 1985-1992, 2018.

17. Gasparri ML, Besharat ZM, Farooqi AA, Khalid S, Taghavi K Besharat RA, Sabato C, Papadia A, Panici PB, Mueller MD and Ferretti E: MiRNAs and their interplay with PI3K/AKT/mTOR pathway in ovarian cancer cells: A potential role in platinum resistance. J Cancer Res Clin Oncol 144: 2313-2318, 2018.

18. Bahrami A, Khazaei M, Hasanzadeh M, ShahidSales S, Joudi Mashhad M, Farazestanian M, Sadeghnia HR, Rezayi M, Maftouh M, Hassanian SM and Avan A: Therapeutic potential of targeting PI3K/AKT pathway in treatment of colorectal cancer: Rational and progress. J Cell Biochem 119: 2460-2469, 2018

19. Guerrero-ZotanoA,MayerIA and ArteagaCL:PI3K/AKT/mTOR: Role in breast cancer progression, drug resistance, and treatment. Cancer Metastasis Rev 35: 515-524, 2016.

20. Gohr K, Hamacher A, Engelke LH and Kassack MU: Inhibition of PI3K/Akt/mTOR overcomes cisplatin resistance in the triple negative breast cancer cell line HCC38. BMC Cancer 17: 711, 2017.

21. Moon du G, Lee SE, Oh MM, Lee SC, Jeong SJ, Hong SK Yoon CY, Byun SS, Park HS and Cheon J: NVP-BEZ235, a dual $\mathrm{PI} 3 \mathrm{~K} / \mathrm{mTOR}$ inhibitor synergistically potentiates the antitumor effects of cisplatin in bladder cancer cells. Int J Oncol 45 : 1027-1035, 2014

22. Yang J, Nie J, Ma X, Wei Y, Peng Y and Wei X: Targeting PI3K in cancer: Mechanisms and advances in clinical trials. Mol Cancer 18: 26, 2019

23. Ceballos MP, Rigalli JP, Ceré LI, Semeniuk M, Catania VA and Ruiz ML: ABC transporters: Regulation and association with multidrug resistance in hepatocellular carcinoma and colorectal carcinoma. Curr Med Chem 26: 1224-1250, 2019.

24. Chen YL, Yang TY, Chen KC, Wu CL, Hsu SL and Hsueh CM: Hypoxia can impair doxorubicin resistance of non-small cell lung cancer cells by inhibiting MRP1 and P-gp expression and boosting the chemosensitizing effects of MRP1 and P-gp blockers. Cell Oncol (Dordr) 39: 411-433, 2016.

25. Ke B, Wei T, Huang Y, Gong Y, Wu G, Liu J, Chen X and Shi L: Interleukin-7 resensitizes non-small-cell lung cancer to cisplatin via inhibition of ABCG2. Mediators Inflamm 2019: 7241418, 2019.

26. Fang Z, Chen W, Yuan Z, Liu X and Jiang H: LncRNA-MALAT1 contributes to the cisplatin-resistance of lung cancer by upregulating MRP1 and MDR1 via STAT3 activation. Biomed Pharmacother 101: 536-542, 2018.

27. Cao Z, Liang N, Yang H and Li S: Visfatin mediates doxorubicin resistance in human non-small-cell lung cancer via Akt-mediated up-regulation of ABCC1. Cell Prolif 50: e12366, 2017.
28. Leung E, Kim JE, Rewcastle GW, Finlay GJ and Baguley BC: Comparison of the effects of the PI $3 \mathrm{~K} / \mathrm{mTOR}$ inhibitors NVP-BEZ235 and GSK2126458 on tamoxifen-resistant breast cancer cells. Cancer Biol Ther 11: 938-946, 2011.

29. Deng L, Jiang L, Lin XH, Tseng KF, Liu Y, Zhang X, Dong RH, Lu ZG and Wang XJ: The PI3K/mTOR dual inhibitor BEZ235 suppresses proliferation and migration and reverses multidrug resistance in acute myeloid leukemia. Acta Pharmacol Sin 38: 382-391, 2017.

30. Wise-Draper TM, Moorthy G, Salkeni MA, Karim NA, Thomas HE, Mercer CA, Beg MS, O'Gara S, Olowokure O, Fathallah $\mathrm{H}$, et al: A phase Ib study of the dual PI3K/mTOR inhibitor dactolisib (BEZ235) combined with everolimus in patients with advanced solid malignancies. Target Oncol 12: 323-332, 2017.

31. Xia A, Li H, Li R, Lu L and Wu X: Co-treatment with BEZ235 enhances chemosensitivity of A549/DDP cells to cisplatin via inhibition of PI3K/Akt/mTOR signaling and downregulation of ERCC1 expression. Oncol Rep 40: 2353-2362, 2018.

32. Torre LA, Siegel RL and Jemal A: Lung cancer statistics. Adv Exp Med Biol 893: 1-19, 2016.

33. Xie J, Xu W, Wu Y, Niu B and Zhang X: Macroporous organosilicon nanocomposites co-deliver Bcl2-converting peptide and chemotherapeutic agent for synergistic treatment against multidrug resistant cancer. Cancer Lett 469: 340-354, 2020

34. Besse B, Garrido P, Cortot AB, Johnson M, Murakami H, Gazzah A, Gil M and Bennouna J: Efficacy and safety of necitumumab and pembrolizumab combination therapy in patients with Stage IV non-small cell lung cancer. Lung Cancer 142: 63-69, 2020.

35. Xin P, Li C, Zheng Y, Peng Q, Xiao H, Huang Y and Zhu X: Efficacy of the dual PI3K and mTOR inhibitor NVP-BEZ235 in combination with imatinib mesylate against chronic myelogenous leukemia cell lines. Drug Des Devel Ther 11: 1115-1126, 2017.

36. Zhou M, Shen S, Zhao X and Gong X: Luteoloside induces G0/G1 arrest and pro-death autophagy through the ROS-mediated $\mathrm{AKT} / \mathrm{mTOR} / \mathrm{p} 70 \mathrm{~S} 6 \mathrm{~K}$ signalling pathway in human non-small cell lung cancer cell lines. Biochem Biophys Res Commun 494: 263-269, 2017.

37. Shen D, Wang Y, Niu H and Liu C: Gambogenic acid exerts anticancer effects in cisplatinresistantnonsmall cell lung cancer cells. Mol Med Rep 21: 1267-1275, 2020.

38. Tavares MR, Pavan IC, Amaral CL, Meneguello L, Luchessi AD and Simabuco FM: The S6K protein family in health and disease. Life Sci 131: 1-10, 2015

39. Lin G, Gai R, Chen Z, Wang Y, Liao S, Dong R, Zhu H, Gu Y, He Q and Yang B: The dual PI3K/mTOR inhibitor NVP-BEZ235 prevents epithelial-mesenchymal transition induced by hypoxia and TGF- $\beta 1$. Eur J Pharmacol 729: 45-53, 2014.

This work is licensed under a Creative Commons Attribution-NonCommercial-NoDerivatives 4.0 International (CC BY-NC-ND 4.0) License. 